\title{
ALTITUDINAL GRADIENTS AND FOREST EDGE EFFECT ON SOIL ORGANIC CARBON IN CHINESE FIR (CUNNINGHAMIA LANCEOLATA): A STUDY FROM SOUTHEASTERN CHINA
}

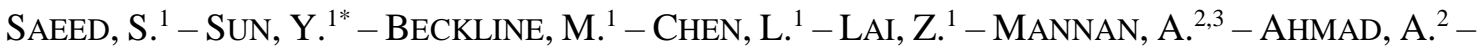 \\ SHAH, S. ${ }^{2}-$ AMIR, M. ${ }^{2}-$ UllaH, T. ${ }^{4}-$ KHAN, A. ${ }^{5}-$ AKBAR, F. ${ }^{6}$ \\ ${ }^{I}$ State Forestry Administration, Key Laboratory for Forest Resources and Environmental \\ Management, Beijing Forestry University, Beijing, China \\ ${ }^{2}$ School of Forestry, Beijing Forestry University, Beijing, China \\ ${ }^{3}$ Punjab Forest Department Government of Punjab, Lahore 54000, Pakistan \\ ${ }^{4}$ School of Nature Conservation, Beijing Forestry University, Beijing, China \\ ${ }^{5}$ School of Soil and Water Conservation, Beijing Forestry University, Beijing 100083, China \\ ${ }^{6}$ Centre for Biotechnology and Microbiology, University of Swat, Swat, Pakistan \\ *Corresponding author \\ e-mail: sunyj@bjfu.edu.cn; phone: +86-136-4129-8528 \\ (Received 19 ${ }^{\text {th }}$ Sep 2018; accepted 26 ${ }^{\text {th }}$ Nov 2018)
}

\begin{abstract}
In forest ecosystems, soil organic matter facilitates carbon sequestration and serves as a sink for atmospheric $\mathrm{CO}_{2}$. Carbon in forest soils plays an important role in mitigating global climate change. Soil carbon density was measured at three depths $(0-20,20-40$, and $40-60 \mathrm{~cm})$ in four different elevation classes sites at the forest exterior and forest interior in the sub-tropical forests of southeastern China. Results showed that soil organic carbon (SOC) varied between 46.48 and $83.12 \mathrm{Mg} \mathrm{ha}^{-1}$ at forest exterior and 50.18 and $90.68 \mathrm{Mg} \mathrm{ha}^{-1}$ at forest interior in different elevation classes. A significant increasing trend in soil organic carbon was found with an increase in elevation at both forest exterior and forest interior. Similarly, a positive correlation between soil organic carbon and elevation was observed at forest exterior $\left(R^{2}=0.87\right.$, $\mathrm{P}=0.0001)$ and forest interior $\left(\mathrm{R}^{2}=0.93, \mathrm{P}=0.0001\right)$. The percentages of soil carbon at $0-20,20-40$, and $40-60 \mathrm{~cm}$ depths at forest exterior and forest interior were 47.24-52.76, 47.23-52.77, and 46.95-53.05\% respectively. Soil bulk density was directly related to soil depth and inversely related to elevation at forest exterior and forest interior. Overall the mean SOC at forest exterior and forest interior was $60.83 \mathrm{Mg} \mathrm{ha}^{-1}$ and $68.20 \mathrm{Mg} \mathrm{ha}^{-1}$ respectively. The study showed that there is a $5.7 \%$ difference in soil carbon density between forest exterior and forest interior which highlights the fact that ignoring edge effects may lead to overestimation of soil carbon density. Therefore, we suggest the establishment of permanent sample plots sites at the forest exterior and forest interior and recommend regular periodic surveys of soil for accurate forest soil carbon measurement.
\end{abstract}

Keywords: forest edge effects, elevation gradients, soil carbon, soil bulk density, sub-tropical forest

\section{Introduction}

At the global scale, the estimated amount of soil organic carbon (SOC) is about three times that of carbon which resides within vegetation and twice that of atmospheric carbon (Li et al., 2016; Smith et al., 2008). Therefore, small fluctuations in SOC pools may influence global carbon budgets and atmospheric $\mathrm{CO}_{2}$ concentrations (Du et al., 2014; Li et al., 2016). Generally, increases in SOC mostly result from biomass carbon being transferred to the soil through decomposition (Shaheen et al., 2017). Hence, SOC is primarily balance by carbon input from vegetation production and output through decomposition (Singh et al., 
2011). These SOC production and decomposition processes are usually a measure of soil climate, disturbance and texture as well as land use, hydrology, and topography (Singh and Rawat, 2013). Moreover, altitudinal gradients and climatic variables (precipitation and temperature) could also affect the carbon pool (He et al., 2016).

The forest covers are recognized as the largest and most effective carbon sinks among terrestrial ecosystems and help to mitigate global climate change (Amir et al, 2018; Beckline et al., 2018; Dar and Somaiah, 2015; Mannan et al, 2018; Saeed et al., 2016). Among these forest ecosystems, mountain forest ecosystems have an important role in the global carbon cycle (Gower, 2003) and store about $26 \%$ of the total terrestrial ecosystem's carbon (Garten Jr and Hanson, 2006). In addition, forests at high altitudes are known to store more SOC compared to similar forests located at lower altitudes (Charan et al., 2012; Wei et al., 2013; Zhu et al., 2010).

Forest logging, including when under legal forest management, can create edge-like conditions inside the forest (Barros and Fearnside, 2016). Forest edge refers to the limit of continuous canopy or boundary in canopy composition and which is substantially different from the corresponding forest interior (Harper et al., 2005; Remy et al., 2016). Forest edges exhibit different microclimatic conditions such as light, temperature, wind, and soil moisture to the corresponding forest interior. These microclimatic differences enable the forest edges to capture relatively more atmospheric carbon than the forest interior (Remy et al., 2016). Several other studies have shown that microclimatic and edaphic conditions are generally different between forest edges and forest interior zones (Burke and Nol, 1998; Camargo and Kapos, 1995; Davies-Colley et al., 2000; Delgado et al., 2007; Didham and Lawton, 1999; Gehlhausen et al., 2000; Jose et al., 1996; Kapos, 1989; Pohlman et al., 2009; Rodrigues, 1998; Williams-Linera et al., 1998). These studies showed that edges experience faster wind speed, higher soil and air temperature, lower soil and air humidity and vapor pressure, than the interior of a forest. Although in a forest ecosystem the effects of an edge on soil carbon have been broadly studied, little literature is available regarding the edge effect on soil carbon along an altitudinal gradients, especially in China.

China has a unique soil carbon distribution due to its diverse climatic profile ranging from subtropical to alpine, and from humid to arid and desert conditions (Yang et al., 2007). In China, most of the research work has been focused on the evaluation of forest biomass carbon stored in China's forests and storage of other forests ecosystem components, such as SOC, has rarely been reported ( $\mathrm{Li}$ et al., 2004; Yu et al., 2010). Compared to the periodic National Forest Inventory (NFI), soil surveys are less frequently conducted in the country, hence the lack of national soil carbon data (Peng et al., 2016; Yang et al., 2014). This lack of sufficient soil carbon data limits the accurate evaluation of soil carbon in China (Pan et al., 2011; Yang et al., 2007; Yu et al., 2010). However, based on soil date from field surveys and global data sets from 1980, soil carbon density in the 0-100 cm soil depth in China's forests were estimated at 115.90-193.55 Mg C ha- ${ }^{1}$ ( $\mathrm{Li}$ et al., 2004; Xianli et al., 2004; Yang et al., 2007; Yu et al., 2007), while Peng et al. (2016) have estimated 136.11$153.16 \mathrm{Mg} \mathrm{C}$ ha $^{-}{ }^{1}$. These variations in soil carbon reflect a lack of contemporary measurements of forests soil carbon. Similarly, no reliable information is available regarding the effect of edges on soil carbon in China's forest. Therefore, this study estimates SOC and bulk density along forest edges and forest interior, at different altitudes in the sub-tropical forest of China's southeast Fujian province. The results show there is a variation in soil carbon and bulk density at forest edges and forest interior at different elevations. 


\section{Materials and methods}

\section{Study area}

The field surveys were conducted in the Jiangle county in China's southeastern Fujian Province, $117^{\circ} 05^{\prime}-117^{\circ} 40^{\prime} \mathrm{E}$ and $26^{\circ} 26^{\prime}-27^{\circ} 04^{\prime} \mathrm{N}$. The area exhibits a humid tropical climate and the frost-free period usually spreads over 287 days. The area receives an average $1699 \mathrm{~mm}$ precipitation annually, while the average yearly temperature is $18.7^{\circ} \mathrm{C}$. The soil type is red, fertile, moist and loamy. The woodland cover of the forest farm is $1887 \mathrm{~km}^{2}$, making-up over $83.9 \%$ of its geographical area. The main tree species are Chinese Fir (Cunninghamia lanceolata), Moso bamboo (Phyllostachys pubescens), and Masson pine (Pinus massoniana) with the most dominant being Chinese Fir. (Guangyi et al., 2017; Hao et al., 2015; Liping et al., 2018). The shrub layer includes species such as Chinese fringe flower (Loropetalum chinense), Rough pellionia (Pellionia scabra), Chinese sweetspire (Itea chinensis) and Rubus (Rubus reflexus) while the herb layer mostly comprises Chinese hicriopteris (Diplopterygium chinense), Herba sarcandrae (Sarcandra glabra), Parasitic Cyclosorus (Cyclosorus parasiticus), and Common lophatherum (Lophatherum gracile).

\section{Soil sample treatment and analysis}

Field surveys were carried out between April and July 2017 in the study area to collect soil samples covering elevations gradient ranging from $40 \mathrm{~m}$ to $1203 \mathrm{~m}$ above sea level (a.s.l) (Fig. 1).
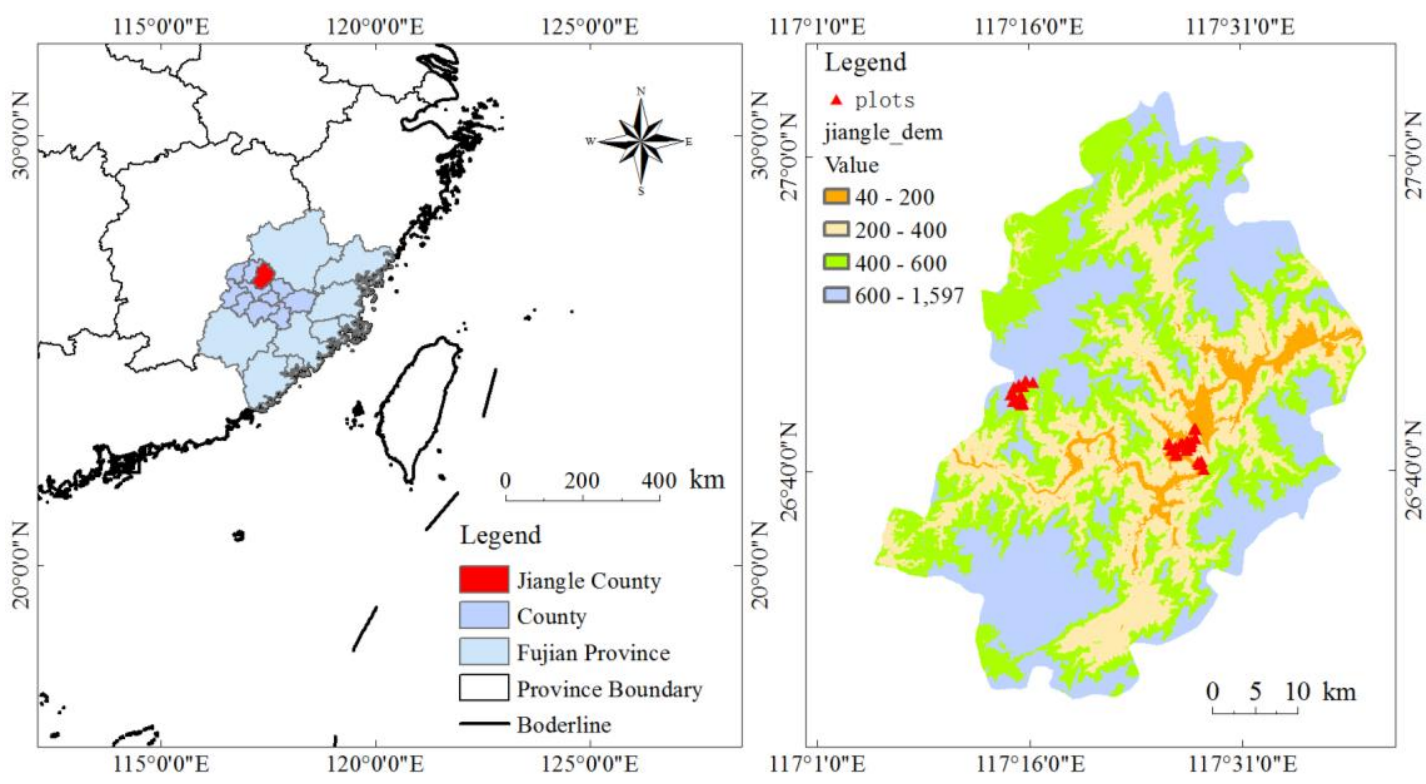

Figure 1. The map and location of the study site

The site characteristics of Cunninghamia lanceolata forest at different elevation are given in Table 1. The area was divided into 4 elevation classes (EC) and the elevation difference of each class was $200 \mathrm{~m}$ (a.s.l). In each EC, 4 sample plots were taken at forest edges and 4 at forest interior. The forest interior plots were laid out at $60 \mathrm{~m}$ distance from the forest edges. The sizes of sample plots ranged between 400 and $600 \mathrm{~m}^{2}$. The soil samples were collected from three sub plots of $(1 \times 1 \mathrm{~m})$ within each 
plot of 400 to $600 \mathrm{~m}^{2}$ at varying depths. The samples were collected at three depth increments in the center of the subplot (that is, of 0-20, 20-40 and 40-60 cm, respectively). The soil samples were collected using a soil auger (Soil auger, Shangyu Hongguanf instrument and Equipment Co., Ltd., China) and soil core of an identified volume of $100 \mathrm{~cm}^{3}$.

Table 1. Characteristics of the Cunninghamia lanceolata forest at different elevation classes in Jiangle County, Fujian Province. Different super scripts in each column represent significant difference $(n=8, p \leq 0.0001$, Alpha $=0.05 . T T B=$ total tree biomass $)$

\begin{tabular}{c|c|c|c|c}
\hline Classes & Diameter range $(\mathbf{c m})$ & Stem density $\left(\mathbf{M g ~ h a}^{\mathbf{- 1}}\right)$ & Basal area $_{\left(\mathbf{m}^{\mathbf{2}} \mathbf{h a}^{\mathbf{- 1}}\right)}$ & $\mathbf{T T B}\left(\mathbf{M g ~ h a}^{\mathbf{- 1}}\right)$ \\
\hline 1 & $4-44$ & $1683.33 \pm 249.76^{\mathrm{a}}$ & $40.09 \pm 11.17^{\mathrm{d}}$ & $180.94 \pm 68.18^{\mathrm{d}}$ \\
2 & $4-38$ & $1716.67 \pm 232.99^{\mathrm{a}}$ & $64.83 \pm 12.57^{\mathrm{c}}$ & $319.77 \pm 80.62^{\mathrm{c}}$ \\
3 & $6-42$ & $1447.92 \pm 239.78^{\mathrm{b}}$ & $94.58 \pm 15.39^{\mathrm{b}}$ & $511.43 \pm 108.73^{\mathrm{b}}$ \\
4 & $8-50$ & $1289.58 \pm 265.61^{\mathrm{b}}$ & $127.69 \pm 5.86^{\mathrm{a}}$ & $732.13 \pm 55.15^{\mathrm{a}}$ \\
Mean & $\mathbf{2 7}$ & $\mathbf{1 5 3 4 . 3 8} \pm \mathbf{2 9 4 . 8 8}$ & $\mathbf{8 1 . 8 0} \pm \mathbf{3 5 . 1 3}$ & $\mathbf{4 3 6 . 0 7} \pm \mathbf{2 2 4 . 1 6}$ \\
\hline
\end{tabular}

The collected samples were weighed and packed in labeled bags. Then the samples were transferred to the Southern Forest, Experimental Base of Beijing Forestry University Sanming Jiangle for further analysis. The samples were first air-dried (Shel Lab Gravity Convection Laboratory Oven SGO3) and then the soil bulk density $\left(\mathrm{g} \mathrm{cm}^{-3}\right)$ was measured for each soil sample. These air-dried samples were manually ground with a pestle and passed through a $0.50 \mathrm{~mm}$ sieve for the determination of SOC as described by (Lu, 1999).

\section{Analysis of soil carbon}

To find out the soil carbon of each collected soil sample, the sub samples ( $1 \mathrm{~g})$ were taken from the labeled sample and analyzed in the laboratory using the oxidizable organic carbon method of (Walkley and Black, 1934). A measure of the soil carbon in Mg ha- ${ }^{1}$ was obtained by calculating the soil bulk density of each sample according to Equation 1.

$$
B D=M S(g) / V C\left(\mathrm{~cm}^{3}\right)
$$

where $\mathrm{BD}=$ Soil bulk density $\left(\mathrm{g} \mathrm{cm}^{-3}\right), \mathrm{MS}=$ Weight of the soil sample $(\mathrm{g})$ and $\mathrm{VC}=$ Volume of the core $\left(\mathrm{cm}^{3}\right)$

The soil organic carbon $\left(\mathrm{Mg} \mathrm{ha}^{-1}\right)$ was calculated from the relationship of the soil bulk density, soil organic carbon and depth increment using Equation 2 (Ahmad and Nizami, 2015; Pearson et al., 2007).

$$
\text { Soil Carbon }\left(\mathrm{Mg} \mathrm{ha}^{-1}\right)=B D\left(\mathrm{~g} \mathrm{~cm}^{-3}\right) \times \operatorname{SOC}(\%) \times T H(\mathrm{~cm}) \times 100(\mathrm{Eq} .2)
$$

where $\mathrm{TH}=$ Thickness of horizon $(\mathrm{cm})$

The difference between the soil carbon at the forest interior and forest edges was obtained using Equation 3.

$$
S C D=S C(\text { in })-S C(e x)
$$


where $\mathrm{SCD}=$ Soil carbon difference $\left(\mathrm{Mg} \mathrm{ha}^{-1}\right), \mathrm{SC}$ (in) $=$ Soil carbon at forest interior $\left(\mathrm{Mg} \mathrm{ha}^{-1}\right), \mathrm{SC}(\mathrm{ex})=$ Soil carbon at forest exterior $\left(\mathrm{Mg} \mathrm{ha}^{-1}\right)$.

\section{Statistical analysis}

MS Excel for Windows 10 was used to analyze soil carbon data. The relationship between SOC and elevation at the forest exterior and forest interior was examined with linear regression (Sigma Plot version 12.5). Similarly, the relationship of soil carbon and bulk density with respect to soil depth was also studied using linear regression (Sigma Plot version 12.5). To test the differences in soil carbon and bulk density at various depths (0-20, 20-40, 40-60), an Analysis of Variance (ANOVA) and Least significant difference (LSD) were performed on the data from forest edges and forest interior. The differences were considered statistically significant at $\mathrm{P}<0.05$. Statistix version 8.1 (Analytical Software, 2005) was used for these analyses. Sigma Plot version 12.5 was used to analyze the relationship between bulk density and elevation at forest exterior and forest interior at various depths.

\section{Results}

\section{Soil organic carbon density}

The mean soil carbon density up to $0-60 \mathrm{~cm}$ depth at the forest exterior and forest interior was $60.83 \mathrm{Mg} \mathrm{ha}^{-1}$ and $68.20 \mathrm{Mg} \mathrm{ha}^{-1}$ respectively. SOC density increased significantly $(P<0.05)$ with increasing elevation (Fig. 2$)$ and decreased with increasing soil depth in all the EC at both the forest exterior and forest interior. The mean SOC at forest edges and forest interior at $0-20 \mathrm{~cm}$ depth was 21.41 and $23.91 \mathrm{Mg} \mathrm{ha}^{-1}$. Similarly, at 20-40 cm and 40-60 cm soil depths the mean SOC at forest exterior and forest interior were 20.24, 22.61, and 19.18, 21.67 $\mathrm{Mg} \mathrm{ha}^{-1}$ respectively Table 2.

Table 2. Soil organic carbon in different depths at forest exterior and forest interior in

Jiangle County, Fujian Province. Different super scripts in each column represent significant difference $(n=8, p \leq 0.0001$, Alpha $=0.05)$

\begin{tabular}{|c|c|c|c|}
\hline \multicolumn{4}{|c|}{ Forest exterior (SOC Mg ha- ${ }^{1}$ ) } \\
\hline Classes & Depth $1(0-20 \mathrm{~cm})$ & Depth $2(20-40 \mathrm{~cm})$ & Depth $3(40-60 \mathrm{~cm})$ \\
\hline 1 & $16.21 \pm 0.20^{\text {no }}$ & $15.50 \pm 0.29^{\mathrm{op}}$ & $14.77 \pm 0.38^{\mathrm{p}}$ \\
\hline 2 & $18.42 \pm 0.89^{\mathrm{jkl}}$ & $17.72 \pm 0.70^{\mathrm{klm}}$ & $16.84 \pm 0.70^{\mathrm{mn}}$ \\
\hline 3 & $21.76 \pm 1.11^{\mathrm{g}}$ & $20.06 \pm 1.38^{\mathrm{hi}}$ & $18.92 \pm 1.43^{\mathrm{ijk}}$ \\
\hline 4 & $29.25 \pm 1.49^{\mathrm{b}}$ & $27.68 \pm 1.68^{\mathrm{c}}$ & $26.20 \pm 2.03^{\mathrm{d}}$ \\
\hline Mean & $21.41 \pm 5.70^{c}$ & $20.24 \pm 5.30^{\mathrm{d}}$ & $19.18 \pm 4.97^{\mathrm{e}}$ \\
\hline \multicolumn{4}{|c|}{ Forest interior (SOC Mg ha- ${ }^{-1}$ ) } \\
\hline 1 & $17.65 \pm 0.71^{\mathrm{lm}}$ & $16.55 \pm 0.63^{\mathrm{mno}}$ & $15.98 \pm 0.59^{\text {nop }}$ \\
\hline 2 & $20.22 \pm 0.77^{\mathrm{h}}$ & $19.27 \pm 0.79^{\mathrm{hij}}$ & $18.40 \pm 0.78^{\mathrm{jkl}}$ \\
\hline 3 & $26.47 \pm 2.28^{\mathrm{cd}}$ & $24.45 \pm 2.52^{\mathrm{e}}$ & $23.11 \pm 2.25^{\mathrm{f}}$ \\
\hline 4 & $31.31 \pm 0.31^{\mathrm{a}}$ & $30.18 \pm 0.40^{\mathrm{ab}}$ & $29.20 \pm 0.63^{\mathrm{b}}$ \\
\hline Mean & $23.91 \pm 6.17^{\mathrm{a}}$ & $22.61 \pm 6.01^{b}$ & $21.67 \pm 5.83^{c}$ \\
\hline
\end{tabular}




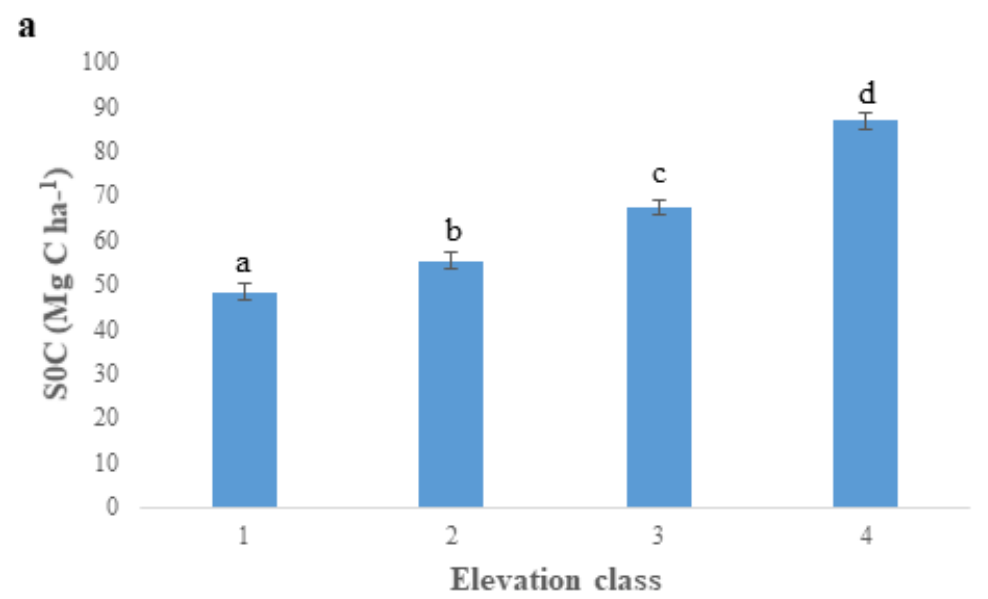

b

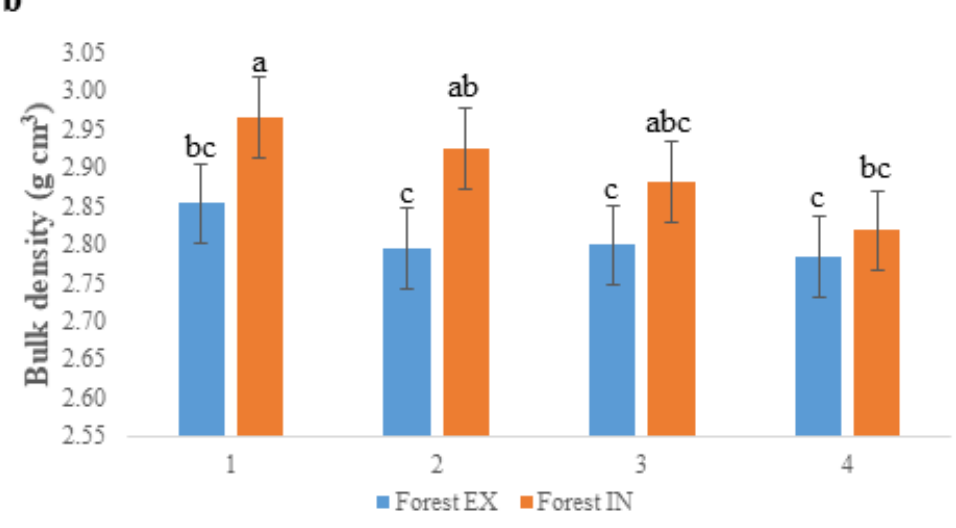

Elevation class

Figure 2. (a) Soil organic carbon in different elevation classes, $p \leq 0.0001$, Alpha $=0.05$ (letter on the bars shows significant differences between the soil carbon density across the elevation classes) and (b) Soil bulk density $\left(\mathrm{g} / \mathrm{cm}^{3}\right)$ in different elevation classes at forest exterior and forest interior, $p \leq 0.0001$, Alpha $=0.05$ (letter on the bars shows significant differences between the soil bulk density along the elevation classes at forest exterior and forest interior)

The percentages of soil carbon density at 0-20, 20-40, and 40-60 cm depths at forest exterior and forest interior were 47.24-52.76, 47.23-52.77, and 46.95-53.05\% respectively. The highest percentage of soil carbon (34.2\%) was observed at $0-20 \mathrm{~cm}$ depth in EC 4 at the forest exterior, whereas the lowest (18.5\%) was observed in EC 1 at the forest interior. At a depth of $20-40 \mathrm{~cm}$, the highest percentage $(34.2 \%)$ of soil carbon was observed in EC 4 at the forest exterior, while the lowest (18.3\%) was observed in EC 1 at the forest interior. Similarly, at 40-60 cm, the highest soil carbon was in EC $4(34.1 \%)$ at the forest exterior whereas the lowest soil carbon was observed in EC $1(18.4 \%)$ at the forest interior. The correlation analysis highlighted a very positive correlation between elevation between SOC and elevation at the forest exterior $\left(\mathrm{R}^{2}=0.87, \mathrm{P}=0.0001\right)$ and forest interior $\left(\mathrm{R}^{2}=0.93, \mathrm{P}=0.0001\right)$.

\section{Soil bulk density}

The soil bulk densities (BD) at different ECs at forest exterior and forest interior are given in Figure $2 b$. Soil bulk density among the ECs at forest exterior ranged between $2.78 \mathrm{~g} / \mathrm{cm}^{3}$ at EC 4 to $2.85 \mathrm{~g} / \mathrm{cm}^{3}$ at EC 1 . The mean soil bulk density at forest exterior 
was $2.81 \mathrm{~g} / \mathrm{cm}^{3}$. The estimated soil BD at the forest interior ranged from $2.82 \mathrm{~g} / \mathrm{cm}^{3}$ at EC 4 to $2.96 \mathrm{~g} / \mathrm{cm}^{3}$ at EC 1, while the mean soil bulk density at the forest interior was $2.90 \mathrm{~g} / \mathrm{cm}^{3}$. The bulk density showed a significant increase $(P<0.05)$ with an increasing in soil depth in all ECs at both the forest exterior and forest interior. Soil bulk density showed significant variation at different depths across all the ECs at forest exterior and forest interior (Fig. 3b). The elevation and soil bulk density were highly negative correlation for different depths. Soil carbon was inversely related to soil bulk density; as soil carbon experienced a decrease with an increase in soil bulk density and vice versa in all ECs at both the forest exterior and forest interior. Similarly, a decreasing trend was observed in the soil bulk density with an increase in elevation.
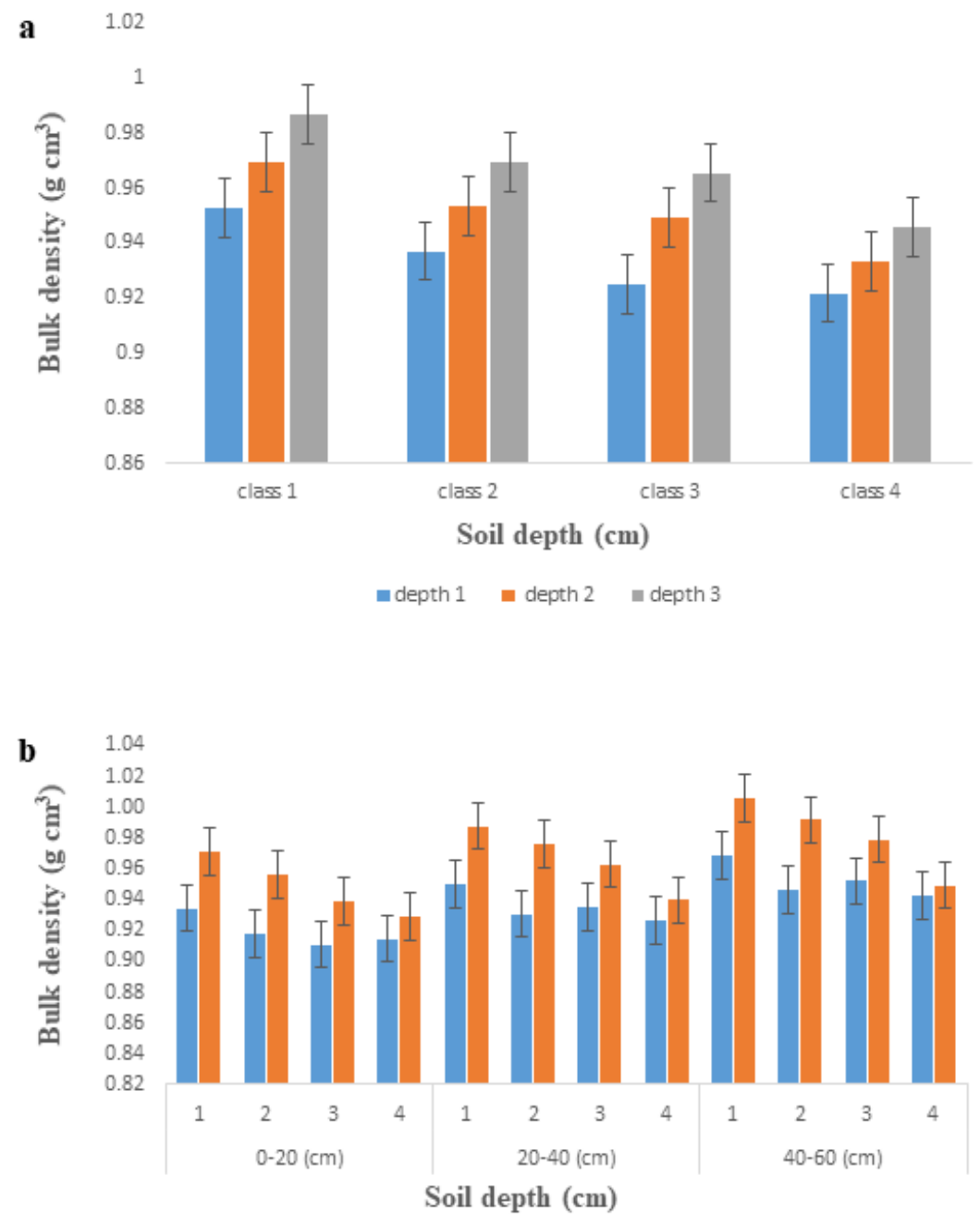

$=\mathrm{EX}=\mathrm{IN}$

Figure 3. (a) Soil bulk density $\left(\mathrm{g} / \mathrm{cm}^{3}\right)$ in different elevation classes at various depths, $p \leq 0.0001$, Alpha $=0.05$ and $(b)$ Soil bulk density $\left(\mathrm{g} / \mathrm{cm}^{3}\right)$ in different depths at forest exterior and forest interior, $p \leq 0.0001$, Alpha $=0.05$

Overall the results showed that there are significant $(P<0.05)$ differences in soil carbon in all the EC (Fig. 2). The highest percentage of soil carbon was in EC 4 $(33.7 \%)$ whereas lowest was in EC 1 (18.7\%). Similarly, the percentage of soil carbon 
at forest exterior and forest interior in EC 1 was (19.1-18.4\%), EC 2 (21.8-21.2\%), EC 3 (25-27.1\%), and EC 4 (34.2-33.2\%), respectively.

\section{Discussion}

The present study investigated the variations in the SOC and bulk density at the forest exterior and forest interior across different EC in the Jiangle county of southeastern China. Soil carbon increased with increasing elevation at both forest exterior and forest interior and more SOC was found at the forest interior when compared to the forest exterior. Soil carbon increased with an increase in precipitation and decreased with increasing in temperature (Jobbágy and Jackson, 2000). A significant positive relationship between soil carbon and elevation was observed at both forest exterior $\left(\mathrm{R}^{2}=0.87, \mathrm{P}=0.0001\right)$ and forest interior $\left(\mathrm{R}^{2}=0.93, \mathrm{P}=0.0001 ;\right.$ Fig. 4$)$.
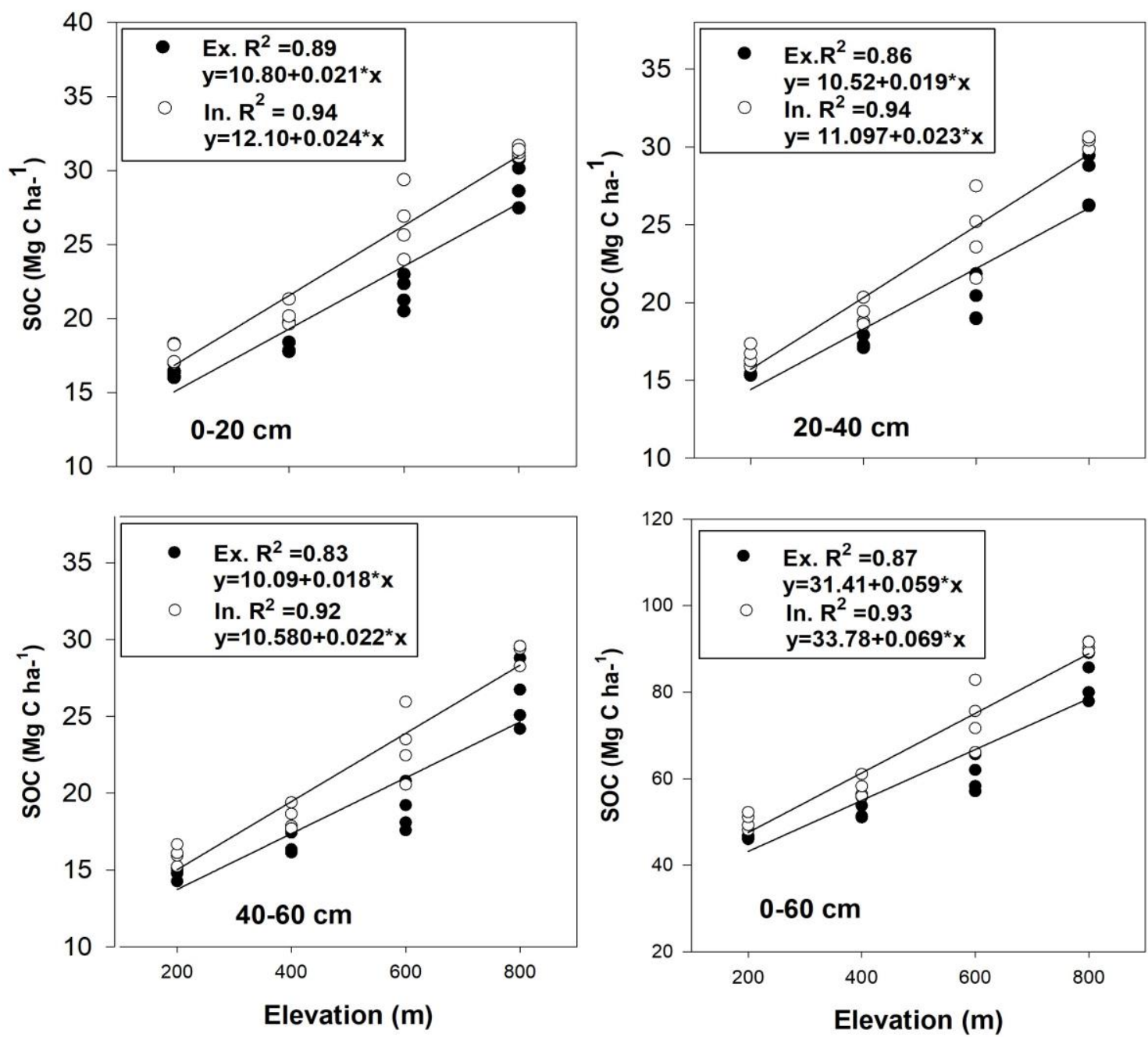

Figure 4. Relationship between elevation and soil organic carbon at forest exterior $(E x)$ and forest interior (In)

These disparities may be due to the lower temperatures and higher rates of precipitation found at higher elevation. According to Jobbágy and Jackson (2000), Yang et al. (2007) 
and Zhu et al. (2010) these differences are due to the distribution of shallower root systems along hilly ecosystems (Jobbágy and Jackson, 2000; Yang et al., 2007; Zhu et al., 2010). Previous research has also reported an increasing trend of soil carbon density with an increase in elevation (Charan et al., 2012; Gupta and Sharma, 2013; Wei et al., 2013; Zhang et al., 2011; Zhu et al., 2010). There was less soil carbon at lower elevations than at higher elevations at both forest exterior and forest interior (Fig. 4 and Table 2). Hence, soils at lower elevations hold significantly lower carbon when compared to soils at higher elevations at both the forest exterior and forest interior. This lower carbon may be attributed to the occurrence of less detritus on the forest floor due to an increase in tree diameter along the elevation gradient. An increase in tree diameter also increases competition among tree species. As a result, there is an increase in the natural shedding of lower branches, hence more deadwood material is present on the forest floor, and consequently more carbon (Charan et al., 2012; Gupta and Sharma, 2013; Wei et al., 2013; Zhang et al., 2011). Furthermore, our results pointed to an overall difference of $5.7 \%$ in soil carbon at the forest exterior and forest interior. In comparison, these finding are not consistent with previous findings (Remy et al., 2016), which showed more soil carbon at forest edges as compared to forest interior. However, some of the findings revealed a slight non-significant increase in carbon at forest edges compared to the interior (Barros and Fearnside, 2016). This variation and discrepancy in soil carbon could also be attributed to disturbance and edge-related factors arising from the combined effects of natural and human actions such as winds, floods, farming, roads, streams, and logging (Chaplin-Kramer et al., 2015). In the study area, potentially influential edge related factors include the presence of farmlands, roads, streams, canopy gaps and logging operations. These edge-related factors reduce the soil carbon mainly through soil compaction and soil erosion due to heavy rains and flooding.

A decrease was observed in SOC density with an increase in soil depth in all the ECs at both forest exterior and forest interior Table 2. Similar findings were reported by Jobbágy and Jackson (2000) and Dar and Somaiah (2015). This decreasing trend of soil carbon with increasing soil depth may be due to slower soil carbon cycling soil carbon at increased depths and compaction (Dar and Somaiah, 2015; Paul et al., 1997; Trumbore, 2000).

\section{Soil bulk density}

In this study we observed a decrease in the soil bulk density with the increasing in elevation at both the forest exterior and forest interior. A negative correlation was observed between soil bulk density at $0-60 \mathrm{~cm}$ depth and elevation at forest exterior $\left(\mathrm{R}^{2}=0.10, \mathrm{P}=0.0001\right)$ and forest interior $\left(\mathrm{R}^{2}=0.42, \mathrm{P}=0.0001\right)$ in all the ECs (Fig. 5). Dar and Somaiah (2015) and Sharma et al. (2010) have also reported the similar relationship between elevation and soil bulk density. The soil organic matter and soil bulk density were inversely proportional. The lower bulk density in soil indicates a higher degree of soil organic matter, good granulation, aeration and higher infiltration (Dar and Somaiah, 2015). Our results also endorse the above explanation.

The present study also indicates that the higher soil bulk density results in lower soil carbon at lower elevation than at higher elevation at both forest exterior and forest interior. In this study, soil bulk density showed an increase with an increased in soil depth in all EC at both the forest exterior and forest interior. This may be due to higher bulk density at greater soil depths in the forest floor, as well as with mixing of minerals in the soil (Schulp et al., 2008). 

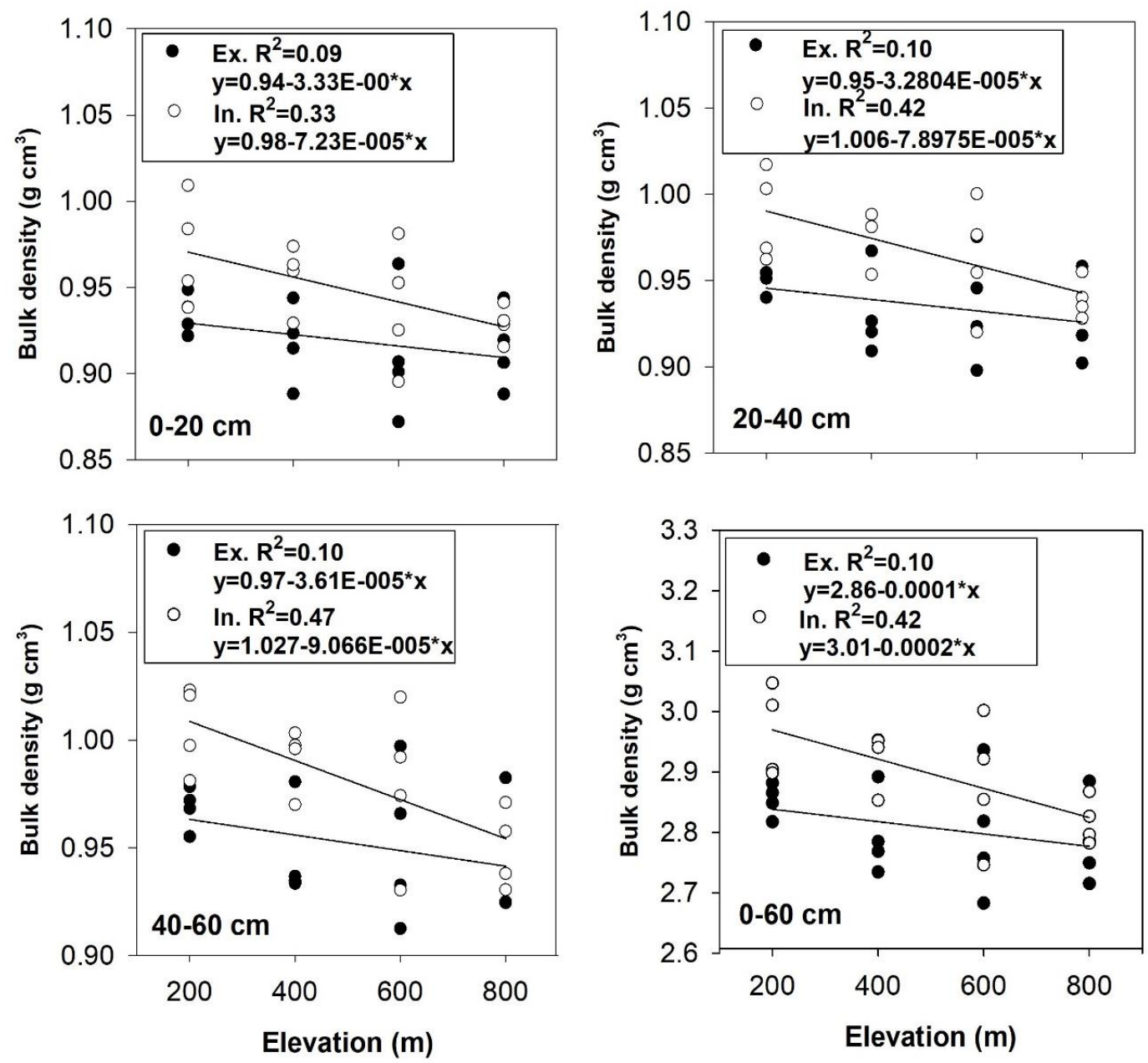

Figure 5. Relationship between soil bulk density and elevation at forest exterior (Ex) and forest interior (In)

\section{Conclusion}

Soil carbon density increased significantly with increasing elevation and decreased with increasing soil depth at both forest exterior and forest interior. Forest soil carbon assessment is critical for policy makers when modeling climate scenarios. However, evidence shows that ignoring edge effects may not account for forest soil carbon precisely. Our results showed that the forest interior stored more soil carbon than the forest edge. The magnitude of the edge effect means that ignoring edge effects overestimates carbon stock by $5.7 \%$. These outcomes suggest that edge effects should be given proper consideration during soil carbon accounting.

Acknowledgements. This study was supported by the National Natural Science Foundation of China (31870620) and the 948 Project of State Forestry Administration of China (2015-4-31).

\section{REFERENCES}

[1] Ahmad, A., Nizami, S. M. (2015): Carbon stocks of different land uses in the Kumrat valley, Hindu Kush Region of Pakistan. - Journal of Forestry Research 26(1): 57-64. 
[2] Amir, M., Liu, X., Ahmad, A., Saeed, S., Mannan, A., Atif Muneer, M. (2018): Patterns of Biomass and Carbon Allocation across Chronosequence of Chir Pine (Pinus roxburghii) Forest in Pakistan: Inventory-Based Estimate. - Advances in Meteorology Article ID 3095891, 8 pages, https://doi.org/10.1155/2018/3095891

[3] Barros, H. S., Fearnside, P. M. (2016): Soil carbon stock changes due to edge effects in central Amazon forest fragments. - Forest Ecology and Management 379: 30-36.

[4] Beckline, M., Yujun, S., Etongo, D., Saeed, S., Mukete, N., Richard, T. (2018): Cameroon must focus on SDGs in its economic development plans. - Environment: Science and Policy for Sustainable Development 60(2): 25-32.

[5] Burke, D. M., Nol, E. (1998): Edge and fragment size effects on the vegetation of deciduous forests in Ontario, Canada. - Natural Areas Journal 18(1): 45-53.

[6] Camargo, J., Kapos, V. (1995): Complex edge effects on soil moisture and microclimate in central Amazonian forest. - Journal of Tropical Ecology 11(2): 205-221.

[7] Chaplin-Kramer, R., Ramler, I., Sharp, R., Haddad, N. M., Gerber, J. S., West, P. C., Mandle, L., Engstrom, P., Baccini, A., Sim, S. (2015): Degradation in carbon stocks near tropical forest edges. - Nature Communications 6: 10158.

[8] Charan, G., Bharti, V. K., Jadhav, S., Kumar, S., Angchok, D., Acharya, S., Kumar, P., Srivastava, R. (2012): Altitudinal variations in soil carbon storage and distribution patterns in cold desert high altitude microclimate of India. - African Journal of Agricultural Research 7(47): 6313-6319.

[9] Dar, J. A., Somaiah, S. (2015): Altitudinal variation of soil organic carbon stocks in temperate forests of Kashmir Himalayas, India. - Environmental Monitoring and Assessment 187(2): 11.

[10] Davies-Colley, R. J., Payne, G., Van Elswijk, M. (2000): Microclimate gradients across a forest edge. - New Zealand Journal of Ecology 1: 11-121.

[11] Delgado, J. D., Arroyo, N. L., Arévalo, J. R., Fernández-Palacios, J. M. (2007): Edge effects of roads on temperature, light, canopy cover, and canopy height in laurel and pine forests (Tenerife, Canary Islands). - Landscape and Urban planning 81(4): 328-340.

[12] Didham, R. K., Lawton, J. H. (1999): Edge structure determines the magnitude of changes in microclimate and vegetation structure in tropical forest fragments. Biotropica 31(1): 17-30.

[13] Du, B., Kang, H., Pumpanen, J., Zhu, P., Yin, S., Zou, Q., Wang, Z., Kong, F., Liu, C. (2014): Soil organic carbon stock and chemical composition along an altitude gradient in the Lushan Mountain, subtropical China. - Ecological Research 29(3): 433-439.

[14] Garten Jr, C. T., Hanson, P. J. (2006): Measured forest soil C stocks and estimated turnover times along an elevation gradient. - Geoderma 136(1-2): 342-352.

[15] Gehlhausen, S. M., Schwartz, M. W., Augspurger, C. K. (2000): Vegetation and microclimatic edge effects in two mixed-mesophytic forest fragments. - Plant Ecology 147(1): 21-35.

[16] Gower, S. T. (2003): Patterns and mechanisms of the forest carbon cycle. - Annual Review of Environment and Resources 28(1): 169-204.

[17] Guangyi, M., Yujun, S., Saeed, S. (2017): Models for Predicting the Biomass of Cunninghamialanceolata Trees and Stands in Southeastern China. - Plos One 12(1): e0169747.

[18] Gupta, M., Sharma, S. (2013): Sequestered organic carbon status in the soils under grassland in Uttarakhand State, India. - Applied Ecology and Environmental Sciences 1(1): 7-9.

[19] Hao, X., Yujun, S., Xinjie, W., Jin, W., Yao, F. (2015): Linear mixed-effects models to describe individual tree crown width for China-fir in Fujian province, southeast China. PloS One 10(4): e0122257.

[20] Harper, K. A., Macdonald, S. E., Burton, P. J., Chen, J., Brosofske, K. D., Saunders, S. C., Euskirchen, E. S., Roberts, D., Jaiteh, M. S., Esseen, P. A. (2005): Edge influence on 
forest structure and composition in fragmented landscapes. - Conservation Biology 19(3): 768-782.

[21] He, X., Hou, E., Liu, Y., Wen, D. (2016): Altitudinal patterns and controls of plant and soil nutrient concentrations and stoichiometry in subtropical China. - Scientific Reports 6: 24261.

[22] Jobbágy, E. G., Jackson, R. B. (2000): The vertical distribution of soil organic carbon and its relation to climate and vegetation. - Ecological Applications 10(2): 423-436.

[23] Jose, S., Gillespie, A. R., George, S. J., Kumar, B. M. (1996): Vegetation responses along edge-to-interior gradients in a high altitude tropical forest in peninsular India. - Forest Ecology and Management 87(1): 51-62.

[24] Kapos, V. (1989): Effects of isolation on the water status of forest patches in the Brazilian Amazon. - Journal of Tropical Ecology 5(2): 173-185.

[25] Li, K., Wang, S., Cao, M. (2004): Vegetation and soil carbon storage in China. - Science in China Series D Earth Sciences - English Edition 47(1): 49-57.

[26] Li, L., Vogel, J., He, Z., Zou, X., Ruan, H., Huang, W., Wang, J., Bianchi, T. S. (2016): Association of soil aggregation with the distribution and quality of organic carbon in soil along an elevation gradient on Wuyi Mountain in China. - PloS One 11(3): e0150898.

[27] Liping, C., Yujun, S., Saeed, S. (2018): Monitoring and predicting land use and land cover changes using remote sensing and GIS techniques-A case study of a hilly area, Jiangle, China. - PloS One 13(7): e0200493.

[28] Lu, R. (1999): Analytical Methods of Soil Agrochemistry. - China Agricultural Science and Technology Publishing House, Beijing, pp. 18-99.

[29] Mannan, A., Feng, Z., Ahmad, A., Liu, J., Saeed, S., Mukete, B. (2018): Carbon dynamics with land use change in Margallah Hills National Park, Islamabad (Pakistan) from 1990 to 2017. - Applied Ecology and Environmental Research 16(3):3197-3214.

[30] Pan, Y., Birdsey, R. A., Fang, J., Houghton, R., Kauppi, P. E., Kurz, W. A., Phillips, O. L., Shvidenko, A., Lewis, S. L., Canadell, J. G. (2011): A large and persistent carbon sink in the world's forests. - Science 333(6045): 988-993.

[31] Paul, E., Follett, R., Leavitt, S., Halvorson, A., Peterson, G., Lyon, D. (1997): Radiocarbon dating for determination of soil organic matter pool sizes and dynamics. Soil Science Society of America Journal 61(4): 1058-1067.

[32] Pearson, T. R., Brown, S. L., Birdsey, R. A. (2007): Measurement Guidelines for the Sequestration of Forest Carbon. - USDA Forest Service, Newton Square, PA.

[33] Peng, S., Wen, D., He, N., Yu, G., Ma, A., Wang, Q. (2016): Carbon storage in China's forest ecosystems: estimation by different integrative methods. - Ecology and Evolution 6(10): 3129-3145.

[34] Pohlman, C. L., Turton, S. M., Goosem, M. (2009): Temporal variation in microclimatic edge effects near powerlines, highways and streams in Australian tropical rainforest. Agricultural and Forest Meteorology 149(1): 84-95.

[35] Remy, E., Wuyts, K., Boeckx, P., Ginzburg, S., Gundersen, P., Demey, A., Van Den Bulcke, J., Van Acker, J., Verheyen, K. (2016): Strong gradients in nitrogen and carbon stocks at temperate forest edges. - Forest Ecology and Management 376: 45-58.

[36] Rodrigues, E. (1998): Edge Effects on the Regeneration of Forest Fragments in South Brazil. - PhD Thesis, Department of Organismic and Evolutionary Biology, Harvard University, Cambridge, MA.

[37] Saeed, S., Ashraf, M. I., Ahmad, A., Rahman, Z. (2016): The Bela Forest ecosystem of District Jhelum. A potential carbon sink. - Pakistan Journal of Botany 48(1): 121-129.

[38] Schulp, C. J., Nabuurs, G.-J., Verburg, P. H., de Waal, R. W. (2008): Effect of tree species on carbon stocks in forest floor and mineral soil and implications for soil carbon inventories. - Forest Ecology and Management 256(3): 482-490.

[39] Shaheen, H., Saeed, Y., Abbasi, M., Khaliq, A. (2017): Soil carbon stocks along an altitudinal gradient in different land-use categories in Lesser Himalayan foothills of Kashmir. - Eurasian soil science 50(4): 432-437. 


$$
-757-
$$

[40] Sharma, C., Gairola, S., Ghildiyal, S., Suyal, S. (2010): Physical properties of soils in relation to forest composition in moist temperate valley slopes of the Central Western Himalaya. - Journal of Forest and Environmental Science 26(2): 117-129.

[41] Singh, H., Kumar, M., Sheikh, M. A., Bhat, J. A. (2011): Forest composition and soil carbon stock in oak and pine forests along altitudinal gradients. - Indian Journal of Ecology 38(special issue): 68-71.

[42] Singh, P. P., Rawat, Y. (2013): Altitude wise variation in soil carbon stock in Western Himalaya. - New York Science Journal 6(8): 140-145.

[43] Smith, P., Fang, C., Dawson, J. J., Moncrieff, J. B. (2008): Impact of global warming on soil organic carbon. - Advances in Agronomy 97: 1-43.

[44] Trumbore, S. (2000): Age of soil organic matter and soil respiration: radiocarbon constraints on belowground C dynamics. - Ecological Applications 10(2): 399-411.

[45] Walkley, A., Black, I. A. (1934): An examination of the Degtjareff method for determining soil organic matter, and a proposed modification of the chromic acid titration method. - Soil Science 37(1): 29-38.

[46] Wei, Y., Li, M., Chen, H., Lewis, B. J., Yu, D., Zhou, L., Zhou, W., Fang, X., Zhao, W., Dai, L. (2013): Variation in carbon storage and its distribution by stand age and forest type in boreal and temperate forests in northeastern China. - PloS One 8(8): e72201.

[47] Williams-Linera, G., Dominguez-Gastelu, V., Garcia-Zurita, M. (1998): Microenvironment and floristics of different edges in a fragmented tropical rainforest. Conservation Biology 12(5): 1091-1102.

[48] Xianli, X., Bo, S., Huizhen, Z. (2004): Organic carbon density and storage in soils of China and spatial analysis. - Acta Pedologica Sinica 41(1): 35-43.

[49] Yang, Y., Mohammat, A., Feng, J., Zhou, R., Fang, J. (2007): Storage, patterns and environmental controls of soil organic carbon in China. - Biogeochemistry 84(2): 131141.

[50] Yang, Y., Li, P., Ding, J., Zhao, X., Ma, W., Ji, C., Fang, J. (2014): Increased topsoil carbon stock across China's forests. - Global Change Biology 20(8): 2687-2696.

[51] Yu, D., Shi, X., Wang, H., Sun, W., Chen, J., Liu, Q., Zhao, Y. (2007): Regional patterns of soil organic carbon stocks in China. - Journal of Environmental Management 85(3): 680-689.

[52] Yu, G., Li, X., Wang, Q., Li, S. (2010): Carbon storage and its spatial pattern of terrestrial ecosystem in China. - Journal of Resources and Ecology 1(2): 97-109.

[53] Zhang, M., Zhang, X.-K., Liang, W.-J., Jiang, Y., Guan-Hua, D., Xu-Gao, W., Shi-Jie, H. (2011): Distribution of soil organic carbon fractions along the altitudinal gradient in Changbai Mountain, China. - Pedosphere 21(5): 615-620.

[54] Zhu, B., Wang, X., Fang, J., Piao, S., Shen, H., Zhao, S., Peng, C. (2010): Altitudinal changes in carbon storage of temperate forests on Mt Changbai, Northeast China. Journal of Plant Research 123(4): 439-452. 